\title{
Potentials of Organic Waste Conversion in a Green Campus Concept
}

\author{
Faaris Mujaahid ${ }^{* 1}$, Argi Mochamad Fauzi ${ }^{1}$, Ramadoni Syahputra ${ }^{1}$, Karisma Trinanda Putra ${ }^{1}$, Kunnu \\ Purwanto ${ }^{1}$ \\ ${ }^{1}$ Department of Electrical Engineering, Faculty of Engineering, Universitas Muhammadiyah Yogyakarta, Indonesia \\ *Corresponding author, e-mail: f.mujaahid@umy.ac.id
}

\begin{abstract}
Development of waste-to-energy plant is regarded as one of a solution to reduce fossil energy dependency and switch to another alternative energy sources, thus needs to be implemented immediately. Research on the potential of organic waste by taking case studies at UMY green campus program can be an illustration that in the future UMY can process this potential into an alternative renewable energy. This research was conducted by studying waste management and data collection methods, such as field observations, discussions with related parties about the waste cycle, and calculations with the concept of gasification. Calculation of biomass produced by organic waste is then supplied to the motor generator for electricity production. Annually, 31.8 tons of organic waste could produce 7.9 kiloliters of biomass and channel it to the power plant system for generating electricity energy as much as $5.3 \mathrm{MWh}$ per year. This number equals to the electricity supply of five small-housing in Indonesian typical house.
\end{abstract}

Keywords: waste-to-energy plant, UMY, Gasification, Biomass

\section{Introduction}

Yogyakarta Muhammadiyah University (UMY) was designated as one of the Green Campus by the Indonesia Green Award (IGA) in 2016. Waste production at UMY continues to increase along with the number of students studying here. With a 25-hectare campus area, a lot of waste is produced from trees that grow around the campus environment, e.g. falling leaves and tree branches. Organic and non-organic waste itself is only disposed of at the TPS, not fully utilized. For nonorganic waste e.g. paper and plastic waste, the campus opens an opportunity for scavengers from outside to be resold to collectors.

In general, the waste in UMY comes from $60 \%$ organic waste and $40 \%$ non-organic waste. Renewable energy sources can be generated from the use of organic waste to produce renewable energy, namely biomass. The biomass energy results, in addition to being used for electricity generation, can also be used for gas needs in the campus canteen thereby reducing the amount of the budget for electricity needs and gas purchases.

In several scientific journals on renewable energy power plants that utilize biomass, fermented organic waste involves thermochemical processes which will later produce biomass with various kinds of gases in it e.g. methane $\left(\mathrm{CH}_{4}\right)$, carbon dioxide $\left(\mathrm{CO}_{2}\right)$, and also other gases [1-3]. In another study, the amount of electricity power generated from waste management at the Benowo Surabaya landfill is 10 megawatts. The amount comes from the total waste that goes into the Benowo landfill, which reaches 1,400 tons every day. Further processing produces 2 megawatts of electricity using the landfill process, while 8 megawatts uses a gasification system [4].

On the other hand, one of the private universities in Indonesia namely Telkom University and Bandung Techno Park develops biodigesters from organic waste that are made into renewable energy that produces 1000 liters of gas (biogas) which can be used for 3-4 canteens and used as fuel for cooking in the Telkom University Canteen [5]. 


\section{Method}

Waste is a collection of the rest of the activities of living things in the form of liquid, solid and gas which has no economic value. The type of waste based on its nature is organic and inorganic waste. Organic waste consists of tree scraps, food scraps, vegetable and fruit scraps that are easily degraded by microbes, while inorganic waste consists of cans, plastics, iron, glass and other materials that cannot be degraded by microbes.

\section{A. Waste Management}

Various waste treatment methods and how to apply as follows:

\section{1) Open Dumping}

By means of simple disposal where garbage is disposed of at a location and then left open without safety it is also left after the location is full.

\section{2) Controlled Landfill}

This method is an increase in open dumping, where garbage that has been piled up is covered with a layer of soil in order to avoid the potential disruption caused by waste. In its operations, leveling and compaction is carried out so that solid waste is denser and more efficient in land use.

\section{3) Sanitary Landfill}

This method is a method developed from the controlled landfill method in which the landfill process is followed by compaction with the soil. This is done continuously in accordance with the plan implemented. Coatings of rubbish with cover soil are carried out every day at the end of operating hours.

\section{4) Incineration}

The incineration method is carried out by burning the collected garbage to reduce the volume of solid waste.

\section{5) Composting}

This method is done by changing organic waste into compost as a fertilizer for plants.

\section{B. PLTSa (Pembangkit Listrik Tenaga Sampah)}

A PLTSa or a waste-to-energy power plant is a power plant that utilizes waste as its main energy source. There are 2 types of energy raw materials that can be used, namely from biomass and biogas.

\section{1) Gasification}

Gasification is the process of a thermochemical energy conversion where the decomposition of biomass is carried out in a device called a gasifier reactor. Decomposition is done by heating using temperatures around $900^{\circ} \mathrm{C}$. Usually the raw material used is from organic waste. There are also types of gas produced from the gasification process, i.e. $\mathrm{CO}, \mathrm{H}_{2}, \mathrm{CH}_{2}, \mathrm{~N}_{2}$, and $\mathrm{CO}_{2}$. Gasification gas e.g. methane gas can be used for various purposes i.e. a fuel source to run a combustion engine, for cooking as a stove fuel, or as fuel for a simple power plant. The process inside the gasifier reactor occurs in several stages such as drying, pyrolysis, oxidation, and reduction explained as follows.

TABLE I

Stages of the gasification process inside the gasifier reactor

Drying Drying is the initial stage for the
gasification process, where the water contained in the biomass is evaporated with hot gas from combustion at the bottom of the reactor, the temperature used ranges from $150{ }^{\circ} \mathrm{C}$.

Pyrolysis Furthermore, in the process of pyrolysis (charcoal), the fuel that has dried will experience heating at a temperature of $500-700^{\circ} \mathrm{C}$ by using hot air so that there will be incomplete combustion making the fuel will decompose into charcoal, organic acids and also in the form of substances the other.

Oxidation This process multiplies the oxidation reaction, where the substances produced are burned with the help of air and produce a gas that is able to burn completely, on the other hand a $\mathrm{CO}_{2}$ gas will be formed which is accompanied by the generation of heat energy. The output produced in this process is the type of gas that can be withdrawn or removed from the reactor. The reactions that occur in the combustion process are as follows:

$$
\mathrm{C}+\mathrm{O}_{2} \longrightarrow \mathrm{CO}_{2}+393.77 \mathrm{~kJ} / \mathrm{mol}
$$

Another burning reaction that takes place is the oxidation of hydrogen contained in the fuel to form water vapor and energy. The reactions that occur are as follows:

$\mathrm{H}_{2}+1 / 2 \mathrm{O}_{2} \longrightarrow \mathrm{H}_{2} \mathrm{O}+742 \mathrm{~kJ} / \mathrm{mol} \mathrm{H}$

Reduction This process is the final process where there will be an exchange of water vapor and $\mathrm{CO} 2$ reduction by carbon charcoal. From this process, the gas produced will increase 
significantly. In this process several chemical reactions also occur, e.i. the water-gas reaction, Bourdouar reaction, shift conversion, and $\mathrm{CO}$ methanation.

\section{Waste Potentials in UMY}

Data is collected by interviewing the parties who know the waste cycle in UMY. Parties involved in the waste problem at UMY include the General Bureau of the Environment section as well as cleaners who know the waste cycle and also second parties such as PJM Gamping (third parties for waste collection), DLH (Local Government division for Natural Environment Services), and scavengers. The following is the estimated data of the total number of waste temporary landfills and tanks in the entire UMY area per month collected from UMY bureau, on-site interviews and observations.

TABLE 2

Overall garbage volume at UMY

\begin{tabular}{|c|c|c|c|c|c|}
\hline NO & MONTH & YEAR & $\begin{array}{c}\text { WASTE } \\
\text { ON UMY } \\
\text { LANDFILL } \\
\text { (KG) }\end{array}$ & $\begin{array}{c}\text { WASTE } \\
\text { ON } \\
\text { TANKS } \\
\text { (KG) }\end{array}$ & $\begin{array}{c}\text { TOTAL } \\
\text { (KG) }\end{array}$ \\
\hline 1 & October & 2017 & 5700 & 300 & 6000 \\
\hline 2 & November & 2017 & 5500 & 300 & 5800 \\
\hline 3 & December & 2017 & 5500 & 300 & 5800 \\
\hline 4 & January & 2018 & 2400 & 80 & 2480 \\
\hline 5 & February & 2018 & 2800 & 100 & 2900 \\
\hline 6 & March & 2018 & 5000 & 100 & 5100 \\
\hline 7 & April & 2018 & 5300 & 300 & 5600 \\
\hline 8 & May & 2018 & 5000 & 108 & 5108 \\
\hline 9 & June & 2018 & 2400 & 80 & 2480 \\
\hline 10 & July & 2018 & 3000 & 100 & 3100 \\
\hline 11 & August & 2018 & 2400 & 80 & 2480 \\
\hline 12 & September & 2018 & 6000 & 480 & 6480 \\
\hline \multicolumn{3}{|c|}{ Average per month } & 4,256 & 169 & 4,425 \\
\hline \multicolumn{3}{|c|}{ Average per day } & 139.4 & 5.6 & 145.5 \\
\hline \multicolumn{3}{|c|}{ Total annually } & $5,107.2$ & 2,028 & 53,100 \\
\hline
\end{tabular}

When viewed according to UMY's area, which is approximately $191,293.46 \mathrm{~m} 2$, from the data in the field, the interview results show that the volume of landfill depends on the weather cycle and the amount of food leftovers from BOGA canteen and SPORTORIUM. If seen in this one-year period UMY could produce 53.1 tons per year and if it is averaged it will produce $4,425 \mathrm{~kg}$ per month or $145.5 \mathrm{~kg}$ per day. Of the 53.1 tons, waste is estimated to consist of $60 \%$ in the form of organic waste and $40 \%$ inorganic waste.

\section{A. Collecting Process at Temporary Landfills and Tanks}

The average volume of landfill per month can reach $4,000 \mathrm{~kg}$ depending on the number of rain cycles. The amount only came from trees falling in the UMY region. To accommodate around 6,000 $\mathrm{kg}$, a landfill with size of $6 \mathrm{~m} \times 7 \mathrm{~m} \times 3.5 \mathrm{~m}$ is needed. The process of collecting garbage from every spot of UMY area dustbin to temporary landfill is carried out every day from morning to evening, transported by 11 yellow carts that can hold up to $50 \mathrm{~kg}$ waste per cart. After being collected at the TPS, it will then be transported by a third party to be disposed of at the Piyungan Landfill every day around 10AM local time.

\section{B. Potential of Organic Waste at UMY}

Based on the area of UMY's green area which reaches around $10,473.1 \mathrm{~m}^{2}$, UMY can produce 31.8 tons of organic waste per year or in average it equals to $88.3 \mathrm{~kg}$ daily. The following table is collected from October 2017 to September 2018 about the garbage output in UMY.

TABLE 3 Overall garbage volume at UMY based on its type

\begin{tabular}{clccc}
\hline NO & MONTH & YEAR & $\begin{array}{c}\text { ORGANIC } \\
(\text { KG })\end{array}$ & $\begin{array}{c}\text { IN- } \\
\text { ORGANIC } \\
\text { (KG) }\end{array}$ \\
\hline $\mathbf{1}$ & October & 2017 & 3600 & 2400 \\
\hline $\mathbf{2}$ & November & 2017 & 3480 & 2320 \\
\hline $\mathbf{3}$ & December & 2017 & 3480 & 2320 \\
\hline $\mathbf{4}$ & January & 2018 & 1488 & 992 \\
\hline $\mathbf{5}$ & February & 2018 & 1740 & 1160 \\
\hline $\mathbf{6}$ & March & 2018 & 3060 & 2040 \\
\hline $\mathbf{7}$ & April & 2018 & 3180 & 2120 \\
\hline $\mathbf{8}$ & May & 2018 & 3064.8 & 2043.2 \\
\hline $\mathbf{9}$ & June & 2018 & 1488 & 992 \\
\hline $\mathbf{1 0}$ & July & 2018 & 1860 & 1240 \\
\hline $\mathbf{1 1}$ & August & 2018 & 1488 & 992 \\
\hline $\mathbf{1 2}$ & September & 2018 & 3888 & 2592 \\
\hline & Average per month & $\mathbf{2 , 6 5 1 . 4}$ & $\mathbf{1 , 7 7 3 . 6}$ \\
\hline & Average per day & $\mathbf{8 8 . 3}$ & $\mathbf{5 9 . 1}$ \\
\hline & Total annually & $\mathbf{3 1 , 8 1 6}$ & $\mathbf{2 1 , 2 8 3 . 2}$ \\
\hline & & & \\
\hline & & & \\
\hline & & & \\
\hline
\end{tabular}




\section{UMY's Electrical Conditions}

The capacity of the electric power source from PLN (Electricity Distribution company owned by Government) is $20 \mathrm{kv}$ medium voltage and the transformer brand TRAFINDO is installed with a capacity of $1250 \mathrm{Kva}$. But this does not guarantee the absolute availability of electricity supply without interruption. So as to meet the need for electricity in the lecture building during the blackout, an electric back-up system in the form of a $500 \mathrm{KVA}$ and $700 \mathrm{KVA}$ generator set are installed. So that the electricity demand can be met when a blackout occurs. The needs of electrical energy during recovery and practicum in all departments in UMY is presented in Table 4.

TABLE 4

Electricity condition at UMY

\begin{tabular}{clcc}
\hline \hline NO & MONTH & YEAR & $\begin{array}{c}\text { ELECTRICITY } \\
\text { (MWH) }\end{array}$ \\
\hline $\mathbf{1}$ & September & 2017 & 307 \\
\hline $\mathbf{2}$ & October & 2017 & 403 \\
\hline $\mathbf{3}$ & November & 2017 & 477 \\
\hline $\mathbf{4}$ & December & 2017 & 426 \\
\hline $\mathbf{5}$ & January & 2018 & 439 \\
\hline $\mathbf{6}$ & February & 2018 & 331 \\
\hline $\mathbf{7}$ & March & 2018 & 341 \\
\hline $\mathbf{8}$ & April & 2018 & 468 \\
\hline $\mathbf{9}$ & May & 2018 & 478 \\
\hline $\mathbf{1 0}$ & June & 2018 & 452 \\
\hline $\mathbf{1 1}$ & July & 2018 & 228 \\
\hline $\mathbf{1 2}$ & August & 2018 & 307 \\
\hline
\end{tabular}

\section{Result and Discussion}

In this study, an analysis of the potential of electrical energy from organic waste was carried out at Yogyakarta Muhammadiyah University. This research uses organic waste media which is disposed of at TPS behind UMY which has the potential to make renewable energy (biomass) using the Gasification method.

\section{A. Organic into Electricity}

The general formula for the method of gasification to make renewable biomass energy can be seen below.

$$
\mathbf{L}=\frac{S}{4}
$$

where:

$\mathrm{L}$ : biomass produced in $\mathrm{kg} / \mathrm{ha}$ (liter)

$\mathrm{S}:$ total waste in $\mathrm{kg}$

\section{4 : gasification ratio $\mathrm{kg}$ to liter}

The energy generated is then used to drive a 5 KVA BG generator (5,000 WATT biomass power generator) from PT BBI which produces electricity. From the above estimates, within one year, UMY could produce 7,954 liters per year and if averaged, it would produce 662.85 liters monthly or 22 liters daily. The following diagram is presented in the last one year from October 2017 to September 2018.

TABLE 5

Estimates of electricity production from the gasification process

\begin{tabular}{rlrrr}
\hline \hline NO & $\begin{array}{c}\text { MONTH } \\
\mathbf{2 0 1 7 - 2 0 1 8}\end{array}$ & $\begin{array}{c}\text { ORGANIC } \\
\text { WASTE } \\
\text { (KG) }\end{array}$ & $\begin{array}{c}\text { BIOMAS } \\
\text { (LITER) }\end{array}$ & $\begin{array}{c}\text { ELECTR } \\
\text { I-CITY } \\
\text { (KWH) }\end{array}$ \\
\hline 1 & October & 3600 & 900 & 600 \\
\hline 2 & November & 3480 & 870 & 580 \\
\hline 3 & December & 3480 & 870 & 580 \\
\hline 4 & January & 1488 & 372 & 248 \\
\hline 5 & February & 1740 & 435 & 290 \\
\hline 6 & March & 3060 & 765 & 510 \\
\hline 7 & April & 3180 & 795 & 530 \\
\hline 8 & May & 3064,8 & 766,2 & 510,8 \\
\hline 9 & June & 1488 & 372 & 248 \\
\hline 10 & July & 1860 & 465 & 310 \\
\hline 11 & August & 1488 & 372 & 248 \\
\hline 12 & September & 3888 & 972 & 647,3 \\
\hline Average per month & $\mathbf{2 . 6 5 1 , 4}$ & $\mathbf{6 6 2 . 8 5}$ & $\mathbf{4 4 1 , 8}$ \\
\hline Average per day & $\mathbf{8 8 , 3}$ & $\mathbf{2 2 , 0 7 5}$ & $\mathbf{1 4 . 7}$ \\
\hline Total annually & $\mathbf{3 1 . 8 1 6 , 8}$ & $\mathbf{7 . 9 5 4 , 2}$ & $\mathbf{5 . 3 0 2 , 1}$ \\
\hline \multicolumn{7}{|l}{} & & & \\
\hline
\end{tabular}

With this energy, it can be used to drive a $5 \mathrm{KVA}$ BG generator unit $(5,000$ watt power biomass generator) from PT BBI which produces electricity. Where the generator of 1.5 liters of biomass gas energy will rotate the generator at $1500 \mathrm{rpm}$ per minute and produce $1 \mathrm{KWh}$ electricity.

\section{B. The Use of Renewable Energy}

From the calculation of the use of 1 streetlight with a power of $20 \mathrm{~W}$ which lights up for 12 hours, it will spend $0.24 \mathrm{Kwh}$ using the formula:

where:

$$
\mathrm{Kwh}=\frac{P_{x t}}{1000}
$$

$$
\begin{aligned}
& \mathrm{P}=\text { power } \\
& \mathrm{t}=\text { hour } \\
& \text { Kwh }=/ 1000 \\
& \text { so: } \frac{\mathbf{2 0} \boldsymbol{x} \mathbf{1 2}}{\mathbf{1 0 0 0}}=\mathbf{0 , 2 4} \mathbf{K w h}
\end{aligned}
$$


Assuming the use of streetlight in the amount of 61 pieces with a power of $20 \mathrm{~W}$ that lights up for 12 hours, it will consume a power of $14.64 \mathrm{Kwh}$.

So if: $1 \mathrm{Kwh}=$ Rp. 1,250,-

Total power saving of:

Per day 14.7 Kwh = Rp. 18,375,-

Per month 441.8 Kwh = Rp. 552,250,-

Per year 5,302.1 Kwh $=$ Rp 6,627,625,-

That way the electricity budget that can be saved is Rp. 6,6276,250,- per year or in average is about Rp. 552,250,- /month.

\section{Conclusion}

Based on the results of research and calculations that have been done, the following conclusions are obtained:

1. Waste generated at UMY per year is around 31.8 tons of organic waste and around 21.3 tons of non-organic waste.

2. The gasification method can convert from organic waste to biomass. By converting around 31.8 tons of organic waste into biomass, within one year, UMY could produce 7,954.2 liters per year.

3. The biomass energy can drive a $5 \mathrm{KVA}$ BG generator ( $0.5 \mathrm{MW}$ biomass power generator) that generates electricity. It is estimated that UMY can produce electricity at 5,302.1 Kwh per year.

\section{References}

[1] Penelitian biogas sebagai sumber pembangkit tenaga listrik di Pesantren Saung Balong Al-Barokah, Majalengka, Jawa Barat. Arifin Maulana, dkk. 2011.

[2] Pemanfaatan Limbah Pertanian sebagai Energi Alternatif Melalui Konversi Termal: Studi kasus di Untiri Kota Malang N D. Siswati dan T. Iskandar. 2012.

[3] Analisis Manfaat Dan Biaya Pembangkit Listrik Tenaga Sampah Untuk Desa Terpecil Di Indragiri Hilir. Syarifudin, 2012.

[4] Jumlah energi listrik yang dihasilkan dari pengelolaan limbah sampah di TPA Benowo, Buchari Chalid. 2016.

[5] Biodigester dari sampah oraganik yang dijadikan energi terbarukan yang menghasilkan 1000 liter, gas (biogas). El Hadi M Rosad. 2016.

[6] Distributed Generation Pembangkit Listrik Tenaga Sampah Kota (PLTSa) Type Incinerator Solusi Listrik Alternatif Kota Medan. Safrizal. 2014.
[7] Analisi Peranan Sampah Kota Sebagai Energi Terbarukan Dalam Penyediaan Energi Terbarukan. Ari, M.Nurdin 2017.

[8] Peran Sumber Energi Terbarukan dalam Penyediaan Energi Listrik dan Penurunan Emisi CO2 di Provinsi Daerah Istimewa Yogyakarta. Rahmat Adiprasetia.

[9] Studi potensi pembentukan biogas dari sampah makanan dan ko-substrat feses sapi untuk energi listrik alternatif . Ardinal, dkk.

[10] Produksi gas metana dari pengolahan sampah perkotaan dengan sistem sel. Arie, dkk. 2010

[11] Karakterisasi bahan sampah, biogas dan lindi pada pengelolaan terintegrasi sampah kota dalam bioreactor. Damsir 2017.

[12] Analisa Ekonomis Pemanfaatan Limbah Organik Sebagai Pembangkit Listrik Tenaga Gas (PLTG) Pada Pasar Tradisional. Jeral H, dkk 2017.

[13] Design of Portable Biogas Reactor Type for Cow Dung Waste. Guyup Mahardhian 2017.

[14] Studi potensi limbah kota sebagai pembangkit listrik tenaga sampah (pltsa) Kota Singkawang. Uray Ibnu.2016.

[15] Perancangan pembangkit listrik tenaga sampah organik zero waste di kabupaten tegal (studi kasus di tpa penujah kabupaten tegal) Abdul Muiz, dkk. 2017.

\section{Authors' information}

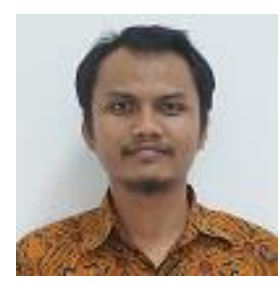

Faaris Mujaahid Hold a bachelor degree in 2010 from Electrical and Electronics Engineering Department, Saxion University of Applied Sciences, the Netherlands. He received a master degree in Sustainable Energy Technologies in 2016 from University of Southampton, UK. ing. Faaris Mujaahid, M.Sc is currently a lecturer in the Department of Electrical Engineering, Faculty of Engineering, Universitas Muhammadiyah Yogyakarta, Indonesia. His main research interest is in LabVIEW and renewable energy (mainly in solar cell material and fabrication technologies).

Argi Mochamad Fauzi is a bachelor student of Electrical Engineering, Faculty of Engineering, Universitas Muhammadiyah Yogyakarta, expected to finish his study in 2019.

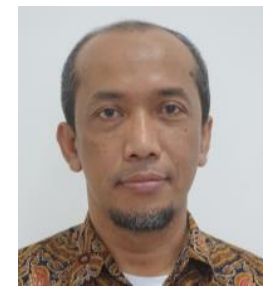

Ramadoni Syahputra received B.Sc. degree from Institut Teknologi Medan in 1998, M.Eng. degree from Department of Electrical Engineering, Universitas Gadjah Mada, Yogyakarta, Indonesia in 2002, and Ph.D degree at the Department of Electrical Engineering, Faculty of Industrial Technology, Institut Teknologi Sepuluh Nopember, Surabaya, Indonesia in 2015. Dr. Ramadoni Syahputra is a Lecturer in Department of Electrical Engineering, Faculty of Engineering, Universitas Muhammadiyah Yogyakarta, Indonesia. His research interests 
are in computational of power system, artificial intelligence in power system, power system control, the application of fuzzy logic in power system, optimization, distributed energy resources, and renewable energy.

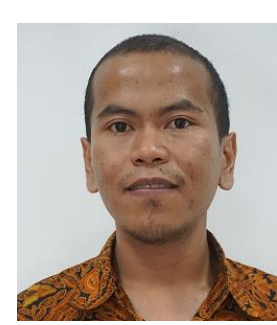

Karisma T. Putra born in Bondowoso on June 19, 1990. Graduated from elementary to senior high school in Bondowoso until 2008. Studied bachelor degree program in Surabaya, precisely in Electronics Engineering Polytechnic Institute of Surabaya (EEPIS) until 2012. He got scholarship program to continue master degree in Institut Teknologi Sepuluh Nopember (ITS) Surabaya. Now, he is doing a doctorate degree in Asia University Taiwan. Karisma is also a lecturer at Electrical Engineering, Faculty of Engineering, Universitas Muhammadiyah Yogyakarta. The main focus of research is the intelligent systems and controls. He engaged in joint research related to the development of food commodity tracking systems and integrated intelligent systems. $\mathrm{He}$ was involved in several competitions in developing smart devices. Pursue the field of electronics and software development since college. Mr. Putra joined in Indonesian's engineer union organization (PII) in 2016. Mr. Putra is also active in writing publications on IEEE society.

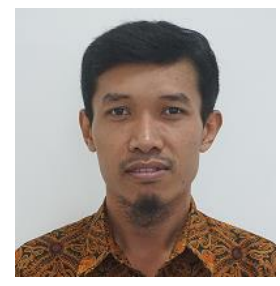

Kunnu Purwanto is a lecturer and researcher in Electrical Engineering Department, Faculty of Engineering, Universitas Muhammadiyah Yogyakarta (UMY). He received bachelor degree from UMY and M.Eng degree from Universitas Gadjah Mada (UGM). Kunnu Purwanto is actively involved in national robotic contest and activities as a delegate from UMY. 